\title{
PEREMPUAN SASAK DALAM NOVEL SRI RINJANI KARYA EVA NOURMA: KAJIAN FEMINISME
}

\author{
Lia Sukmawati, \\ Program Pascasarjana, Universitas Sebelas Maret \\ Email: sukmawatilia5@gmail.com \\ Bani Sudardi, \\ Universitas Sebelas Maret \\ Email: banisudardi@yahoo.com \\ Dwi Susanto \\ Universitas Sebelas Maret \\ Email: dwisastra81@gmail.com
}

\begin{abstract}
ABSTRAK
Novel Sri Rijani berlatar kehidupan perempuan Sasak dan kemiskinan di Lombok. Novel ini memperlihatkan perjuangan perempuan Sasak dalam melakukan perubahan melalui pendidikan dan dalam bayang-bayang kekuasaan laki-laki. Penelitian ini bertujuan untuk mengetahui representasi perempuan Sasak yang tergambar dalam novel Sri Rinjani karya Eva Nourma. Metode yang digunakan dalam penelitian ini adalah metode deskriptif analisis dengan pendekatan feminisme, terutama masalah representasi/identitas perempuan Sasak. Hasil penelitian ini menunjukkan bahwa representasi perempuan Sasak ditampil sebagai sosok pribadi yang moderat, berpikiran terbuka, terdidik, mandiri, dan bertanggung jawab terhadap dirinya. Gambaran ini ditunjukkan untuk mengajak peremopuan Sasak berubah seperti yang digambarkan tersebut. Tujuannya adalah untuk melakukan gerakan perubahan sosial di masyarkat Sasak.
\end{abstract}

Kata kunci: novel, eksistensi, perempuan Sasak

\begin{abstract}
The novel which has historical background of women's life and poverty in Lombok shows the uniqueness in describing Sasak women's struggle to make changes through education which is always in the power of men. This research generally aims to obtain a description of the existence of Sasak women in Eva Nourma's novel of Sri Rinjani. The method used in this research is descriptive analysis method. the approach of feminism is done to know the existence of Sasak women as individuals and as part of the community. The results of this study indicate that the presence of Sasak women described through Sasak Sri Rinjani women appear as an open-minded and intelligent, independent and responsible person. Thus, the new perception that the figure of Sasak women in this novel does not occupy a subordinate position, he is the actor of the act.
\end{abstract}

Keywords: novel, existence, Sasak woman 


\section{PENDAHULUAN}

Telaah tentang manusia dan kemanusiaan selalu menarik untuk dihadirkan dalam karya sastra. Dengan karya sastra, masyarakat dapat melihat representasi melihat kehidupan yang dihadirkan dalam karya sastra. Selain sebagai refleksi keadaan sosial masyarakat, karya sastra merupakan alat untuk mencermati gejala sosial yang muncul, yakni menempatkan karya sastra dalam konteks dunia sosial (Susanto, 2016, h.167-168). Keberadaan individu merupakan sebuah fenomena yang menarik untuk dilihat dan diamati. Sebab, persoalan mengenai keberadaan individu sebagai bagian dari dunia sosial merupakan sebuah gejala yang patut dipertimbangkan. Manusia selalu berusaha untuk mencari dan menempatkan posisinya.

Perempuan Sasak, sebagaimana yang digambarkan dalam novel Sri Rinjani (2011) karya Eva Nourma, merupakan nama yang diberikan untuk perempuan yang asli kelahiran di Lombok. Perempuan Sasak mengasah ketekunan hidup mereka salah satunya dengan bertenun (nyesek). Aktivitas tidak hanya untuk menambah penghasilan ekonomi, tetapi menyatu dalam sistem tradisi yang juga menentukan karakter mereka. Perempuan Sasak juga seperti masyarakat Sasak pada umumnya, adalah tipikal masyarakat polos, jujur dan ramah. Mungkin saja mereka terpengaruh oleh pemberian nama suku mereka yaitu Sasak yang bermakna Saq Saq Lombok ( hidup lurus, polos, tidak macam-macam). Sikap hidup lurus dan apa adanya membuat mereka lebih fokus pada hal-hal kecil di dekat mereka saja, tanpa melupakan hal-hal besar yang menjadi target hidup mereka. Masyarakat Lombok umumnya adalah masyarakat agraris (pertanian). Sekitar 90\% masyarakat Lombok memiliki lahan persawahan, dalam perkembangannya, bertani menjadi sistem budaya yang unik. Tugas perempuan Sasak dalam hal tersebut dalam tradisi Sasak dikenal dengan istilah memano (mengantar makananan ke sawah. Tipikal atau streotipe yang demikian inilah yang digmabarkan berkebalikan atau berbeda dalam novel yang ditulis oleh Eva Nourma, Sri Rinjani (2011). Perempuan Sasak dalam novel Sri Rinjani (2011) merupakan 
perempuan yang ditampilkan melalui sosok Sri Rinjani. Tokoh ini terlahir dari lingkungan yang miskin. Budaya patriarki ikut serta dalam memberikan karakter atas perempuan. Namun, novel Sri Rinjani (2011) ini justru menghadirkan para tokohnya menjadi perempuan kuat dan mandiri. Lingkungan sosial yang dihadirkan dalam teks novel ini justru tidak menjadikan diri sang tokoh cerita untuk terjebak pada pilihan kemiskinan dan kebodohan, melainkan sebaliknya. Sang tokoh cerita dihadirkan sebagai peremopuan sasak moderat, yakni perempuan Sasak yang mandiri untuk melawan kemiskinan dengan memikirkan pendidikan sebagai jalan keluar yang terbaik. Dukungan keluarga juga turut serta dalam membangun cita-cita dan keberadaan perempuan Sasak, seperti yang tergambar dalam novel ini.

Sebagai perempuan Sasak, tokoh Sri Rinjani mengalami proses perkembangan pemikiran yang mengarah pada bentuk kesadaran terhadap keberadaan dirinya. Dalam novel ini, Sri Rinjani yang sejak lahir sangat dekat dengan ayahnya dan memiliki kebebasan untuk memilih jalan hidup, termasuk bagaimana dia sejak kecil menghabiskan waktu untuk memelihara kambing-kambing peliharaannya. Perjuangan Sri Rinjani melawan kemiskinan, menghilangkan stereotip perempuan Sasak menjadi salah satu daya tarik dalam penelitian ini.

Selain itu, sosok pengarang sebagai bagian dari anggota masyarakat atau kelompok sosial juga memberikan arah dan sumbangan yang penting dalam proses penciptaan novel ini. Eva Nourma merupakan perempuan yang terdidik dalam konteks pendidikan modern dan terlibat dalam organisasi pembela perempuan. Hal ini sekaligus menunjukkan bahwa novel Sri Rinjani (2011) yang ditulis oleh Eva Nourma merupakan bagian dari simbol pemikiran dan gagasannya terhadap citra dan keberadaan perempuan. Hal ini menunjukkan bahwa pengarang sebagai wakil kelompok sosial dalam mempresentasikan keberadaan perempuan Sasak. Fakta ini sekaligus menandakan bahwa pengarang sebagai wakil kelompok memiliki gagasan dan pandangan yang serupa dengan kelompoknya (Goldmann, 1977). 
Novel Sri Rinjani (2011) karya Eva Nourma merupakan representasi kelompok sosial yang diwakili oleh pengarang tentang keberadaan atau representasi perempuan. Melalui representasi perempuan, Eva Nourma hakikatnya melakukan sebuah gerakan sosial terhadap perempuan Sasak. Gerakan ini merupakan sebuah gerakan yang bersifat kultural yang bertujuan untuk memperdayakan perempuan Sasak terutama melalui penyadaran sosial bahwa perempuan Sasak memiliki kesempatan dan potensi yang sama dengan laki-laki. Novel Sri Rijani (2011) ini merupakan cara dalam menempatkan perempuan Sasak dalam konteks dunia sosialnya.

Berdasarkan hal tersebut, masalah utama dalam penelitian ini adalah representasi perempuan Sasak yang digambarkan oleh novel Sri Rinjani (2011) karya Eva Nourma. Dari representasi tersebut, gagasan lain yang diekplorasi adalah tentang pandangan pengarang terhadap perempuan Sasak dalam konteks dunia sosialnya.

\section{TEORI DAN METODE PENELITIAN}

Secara etimologis feminis berasal dari kata femme (woman) berarti perempuan (tunggal) yang bertujuan untuk memperjuangkan hak-hak perempuan sebagai kelas sosial. Dalam hubungan ini perlu dibedakan antara male dan female (sebagai aspek perbedaan biologis sebagai hakikat alamiah), masculine dan feminine (sebagai aspek perbedaan psikologis dan struktural). Dengan kata lain, masculine feminine ditentukan secara kultural, sebagai hasil pengaturan kembali infrastruktur material dan superstruktur ideologis. Feminitas adalah pengertian psikologis struktural seseorang yang tidak dilahirkan sebagai perempuan melainkan menjadi perempuan. Oleh karena itu, hal yang ditolak oleh kelompok feminis adalah anggapan bahwa perempuan merupakan konstruksi negatif, perempuan sebagai makhluk takluk, perempuan yang terjerat ke dalam dikotomi sentral marginal, superior inferior (Ratna, 2007, h.184-185).

Atas dasar kelemahankelemahannya secara biologis, perkembangan peradaban selanjut- 
nya selalu menempatkan perempuan sebagai inferior. Maka dari itu, salah satu tokoh feminisme eksistensialis yaitu Simone de Beauvoir mengatakan bahwa dunia perempuan selalu akan dimasukkan ke dalam dunia laki-laki sebagai bukti penguasaan laki-laki terhadap perempuan (Beauvoir, 2006). Menurut Simone de Beauvoir, melalui Wibowo (2008), laki-laki dinamai "laki laki" Sang Diri sedangkan "perempuan" Sang Liyan. Perempuan yang sadar akan kebebasan mereka dapat dengan leluasa menentukan jalan hidupnya. Menurut Beauvoir, perempuan dapat pergi bekerja dan mengkatualisasikan diri secara maksimal. Perempuan bisa menjadi intelektual dan tidak perlu khawatir akan kemampuannya jika dilihat dari keterbatasan biologisnya. Hal yang terpenting adalah bahwa perempuan harus dapat menolak dijadikan objek. Perempuan juga bisa mengobjekkan laki-laki. Dalam proses menuju transedensi menurut Beauvoir (2016), terdapat empat strategi yang dapat dilakukan (1) perempuan dapat bekerja, (2) perempuan dapat menjadi seorang intelektual, (3) perempuan dapat bekerja untuk mencapai transformasi sosialis masyarakat, dan (4) perempuan dapat menolak ke-Liyan-annya dengan mengidentifikasi diri melalui pandangan kelompok dominan dalam masyarakat. Perempuan, ketika mulai eksis untuk dirinya sendiri dapat menciptakan kebebasannya sendiri masa depan tetap terbuka lebar (Thornham, 2010, h.47).

Salah satunya, kritik sastra feminis mempersoalkan bagaimana perempuan dihadirkan melalui karya sastra. Gagasan ini merupkana gagasan mimetik tentang kehidupan perempuan. Namun, gagasan yang demikian memiliki maksud sebagai usaha atau sebuah gerakan penyadaran teerhadap pembaca, bahwa perempuan yang dihadirkan dalam karya sastra atau citra perempuan memiliki maksud yang perlu direkonstruksi atau diselidiki. Sebuah pertanyaan adalah apakah penghadiran perempuan dalam karya sastra sebagai sebuah praktik politik dari para pengarang yang menyampaikan maksud dan tujuan kelompoknya. Kritik sastra feminis yang demikian ini juga menjadi bagian cara membongkar representasi perempuan dalam karya 
sastra atau sering disebut sebagai citra perempuan dalam karya sastra.

Citra atau representasi perempuan dalam karya sastra berbeda dengan eksitensi perempuan seperti yang digagas oleh Simone de Boavoiur. Eksistensi menurut Sartre dalam Tong (2006, h.256) mendahului esensi. Dengan perkataan lain, kita tidak hanya sebagai organisme hidup yang amorfus (tidak mempunyai bentuk yang ajeg) hingga kita menciptakan identitas yang terpisah dan esensial bagi diri kita sendiri melalui tindakan yang sadar melalui pilihan dan keputusan, menegaskan kembali tujuan dan proyek lama, serta menegakkan tujuan dan proyek yang baru. Sementara itu, representasi dalam konteks ini diartikan bahwa perempuan dihadirkan dalam karya sastra sebagai upaya politis oleh kelompok sosilanya. Hal ini dijadikan sebagai satu usaha dalam melakukan gerakan sosial.

Penelitian ini berjenis penelitian kualitatif. Data berupa isi teks novel Sri Rinjani (2011), gagasan-gagasan yang ada di dalamnya, kehidupan sosiologis pengarang, ideologi atau pandangan hidup pengarang, dan berbagai informasi yang berhubungan dengan topik penelitian. Objek penelitian ini adalah novel Sri Rinjani (2011) sebagai objek material dan pengambaran perempuan dalam novel tersebut sebagai bagian dari praktik sosial sebagai objek formalnya. Cara mengumpulkan data dilakukan dengan wawancara, teknik membaca dan mencatat.

Teknik interpretasi data dilakukan dengan cara menghubungkan fakta sastra yang ada di dalam teks Sri Rinjani yang berhubungan dengan representasi perempuan dengan kehidupan sosiologis masyarakat Lombok. Namun, hal itu perlu dijembatani dengan gagasan dunia atau pandangan hidup sang pengaranag sebagai wakil kelompoknya agar tidak terjebak pada "mencocokkan" fakta sastra dengan fakta sosial. Teknik yang digunakan adalah teknik dialektik, yakni menghubungan berbagai data yang ada dan diinterpretasikan dengan kritik sastra feminis. 
HASIL DAN PEMBAHASAN

\section{Representasi Perempuan Sasak dalam Novel Sri Rinjani (2011)}

Representasi atau gambaran perempuan dalam novel Sri Rinjani (2011) ini secara umum digambarkan sebagai individu yang tumbuh sebagai anak yang bergumul dengan realitas sosial dan budaya patriarki. Sang tokoh perempuan, sebagai contohnya, Sri Rinjani di lahirkan dari rahim seorang perempuan Sasak juga yang masa kecilnya tumbuh di desa Selayar, perempuan pemecah batu. Dia dihadirkan sebagai pekerja, seperti harus menjadi pemecah batu sebagai sumber pendapatan untuk menghalau rasa lapar. Dia lahir dari keluarga yang miskin, sehingga sejak kecil harus mampu melihat peristiwa-peristiwa yang belum layak untuknya.

Itulah lempengan wajah ibuku. Lempengan wajah perempuan Sasak yang terserak di desa miskin, membuat luka terasa tak berdetak. Wajah perempuan Sasak berserakan di ratusan desa serupa dengan Selayar. Namun tiada hingga terabaikan. (h. 6)

Sejak kecil Sri Rinjani sudah melalui banyak hal tentang keadaan sosial yang menjadi kenyataan dalam kehidupannya bersama kedua orang tuanya. Nama Sri Rinjani yang sejak kecil selalu menjadi bahan tertawaan teman-temannya karena Sri Rinjani merupakan bahasa Sasak yang berarti Pinggir Gunung Rinjani. Namun, seorang ayah telah memiliki harapan dan cita-cita besar di balik pemberian nama tersebut untuk anaknya. Hal ini menunjukkan bahwa dari identitas saja, perempuan sudah dipandang dari sisi negatif, seperti bodoh dan tidak berdaya. Perempuan diibaratkan sebagai sosok yang liar, alam yang terbelakang. Namun, nama yang merepresentasikan alam ini memberikan bukti bahwa "alam" memberikan kehidupan. Gunung Rinjani adalah penjaga keselarasn alam dan kesimbangan hidup.

"Sri Rinjani nama yang indah sayang. Jika suatu saat kamu pergi ke negeri-negeri terjauh untuk melihat peradaban manusia yang tidak pernah terbayang dalam benakmu sekarang, kamu pasti akan bangga pada tanah asalmu karena gunung Rinjani hanya ada di Lombok. Tidak ada di Amerika, tidak ada juga di Inggris, begitu juga di Italia. Bahkan kamu tidak akan pernah menjumpai pergunungan bernama gunung Rinjani di seluruh penjuru dunia". (h.20).

Secara biologis, dia memang terlahir dengan identitas sebagai perempuan Sasak, terlebih ibunya pun lahir dari rahim seorang 
perempuan Sasak. Namun, masyarakat melihat ayah Sri Rinjani adalah seorang pengembala kambing dan petani berasal dari Desa Perigi, yang terletak di sebelah timur bagian utara Pulau Lombok. Sri Rinjani lebih banyak menghabiskan waktunya untuk belajar berladang dan mengembala kambing-kambingnya. Hal ini sekaligus menunjukkan bahwa Sri Rinjani berasal dari suatu daerah yang pelosok dan membangun sebuah citra keterbelakangan dan kebodohan atau ketertinggalan. Secara kultural dan sekaligus dalam pandangan dunia modern, Sri Rijani dihadirkan sebagai tokoh perempuan yang terbelakang, tidak terdidik, dan bukan dari kalngan keluarga atau lingkungan yang modern. Hal ini terlihat dari kutipan berikut ini:

"Aku sering duduk di atas bukit sambil memandang jauh ke timur. Membiarkan kambing-kambing liar mencari makan sendiri di ladang menghampar. Masa kanakku pun diperas berfikir tentang pulau yang mekahirkanku". (h. 45)

Representasi perempuan Sasak yang menonjol dalam novel ini ditunjukkan melalui prinsip hidup yang dimiliki oleh tokoh Sri Rinjani. Dia ingin menemukan masa depan yang lebih cerah melalui tekad untuk terus memperjuangkan kehidupannya. Hal ini dilakukan melalui dunia pendidikan. Sebab, baginya, pendidikan dapat mengubah cara hidup dan jalan hidup sehingga terbebas dari kemiskinan. Oleh sebab itu, dia terus bekerja sebagai tukang masak di sebuah pondok pesantren. Akan tetapi, ada beberapa alasan dari tokoh Sri Rinjani ini untuk kembali ke rumahnya, di Desa Perigi. Hal itu terlihat dalam dialog antara Sri Rinjani dan Pak Kamil berikut ini.

"Apakah ibu ragu bahwa aku sudah dewasa? Aku merasa sudah matang untuk apapun yang akan terjadi pada diriku, Bu. Anak ibu sendiri". "Apakah melanjutkan kuliahmu adalah jalan yang terbaik meski tanpa ayahmu bersama kita, Nak ?". "Mengapa ibu putus asa begitu? Banyak hal yang membuat kita bertahan hidup. Percayalah, $\mathrm{Bu}$. Pasti ada keindahan di balik semua yang terjadi ini. Tuhan menyayangi kita. Lagipula ibu seorang perempuan yang mengajarkan aku cara menghadapi luka. Aku ingin menjadi seperti ibu". (h.144)

Alasan yang dikemukakan tokoh Sri Rinjani memperlihatkan cara dia berpikir dan membangun masa depannya sebagai perempuan Sasak. Dia sendiri yang memilih jalan hidup yang menjadi pilihannya. Dia mengambil suatu keputusan yang 
terbaik bagi dirinya. Akan tetapi, sebagai anak, sang tyokoh ini tetap menanti persetujuan dari ibunya. Sang ibu pun mengizinkan Sri Rinjani untuk kembali ke Pancor. Hal ini menunjukkan bahwa dalam mengambil suatu keputusan yang membawa jalan hidup seseorang perempuan, pertimbangan dari pihak yang lian masih mengikutinya. Simbol Ibu sebagai sosok yang harus dipertimbangkan merupakan sebuah simbol dari adat dan tradisi. Hal ini menunjukkan bahwa Sri Rinjani masih terikat dengan tatanan adat dan tradisi dalam melanjutkan gagasan dan pikirannya. Perempuan tetap tidak berani melanggar adat dan kebudayaan, yang merupakan simbol dari "kepandaian dan konstruksi kehidupan" yang partiarkhis. Sebab, analogi nature dan culture tetap memainkan peran dalam konteks tersebut.

Tokoh Sri Rinjani ini berusaha membuat sebuah citra atau konstruksi tentang perjuangan perempuan dan menghapus streotipe peremuan Sasak. Hal ini ditunjukkan yang salah satunya dengan keinginanya untuk tinggal di Pancor. Baginya, tempat itu akan memberi kesempatan dalam mengenal dunia baru. Melalui pengalamannya, sang tokoh pun mencapai satu titik kesadaran bahwa laki-laki lah yang menguasai dunia ini. Ia juga seakan diingatkan tidak boleh gegabah dalam bertindak. Untuk itu dirinya hadir sebagai perempuan yang memiliki kuasa atas dirinya sendiri, akan eksistensi dirinya sendiri. Sri Rinjani juga menunjukkan eksistensinya melalui kecerdasan intelektualnya, dengan menguasai beberapa kecerdasan dalam mengelola emosional dan kekuatan sosial, Sri Rinjani dapat mencapai keinginannya. Pilihan yang diambilnya adalah pilihannya sendiri. Sri Rinjani secara total melepaskan dirinya dan menjadikan dirinya sang diri yang mandiri dan bebas dari segala bentuk keterikatan, menerima eksistensinya sebagai kesendirian yang mutlak. Sri Rinjani berusaha membebaskan dirinya dari keliyanan, seperti yang terlihat dalam kutipan di bawah ini.

Selain itu ibu mengabarkan, pak Kamil sudah memprsiapkan tanah yang cukup luas. Siapa tahu kelak, aku berencana membangun tempat pendidikan bagi anak-anak tidak mampu di desa Perigi. (h.190) 
Menjadi istri dari sahabat almarhum ayahnya yang sepatutnya lebih tepat menjadi ayahnya, bukanlah tujuan akhir yang ingin diperoleh Sri Rinjani dan ibunya. Sri Rinjani tetap berjalan meraih tujuannya. Dengan menjadi istri dari pak Kamil yang memberikannya jalan terbaik untuk masa depannya, kebaikan pak Kamil sebagai sahabat almarhum ayahnya sedikitpun tidak berniat menyentuhnya, tetapi pernikahan mereka hanyalah sebagai jalan keluar agar terhindar dari prasangka buruk masyarakat. Sri Rinjani memperoleh kebebasan yang tidak terbatas. Ia menciptakan sendiri situasi yang hampir sama dengan laki-laki yang berkuasa. Pada biasanya perempuan hanya sebagai makhluk yang lemah lembut dan lebih pantas hanya berada di dalam ruangan domestik dan secara tidak langsung lebih banyak perempuan Sasak pun menginternalisasikan cara pandang asing bahwa laki-laki adalah esensial dan perempuan tidak esensial. Sejalan dengan konsep (Beauvior, 2016, h.504) yang mengatakan perempuan telah disosialisasikan sejak mereka kanak- kanak untuk menerima, menunggu, bahkan bergantung.

Dari hal tersebut Beauvior mengungkapkan bahwa unsur ketergantungan perempuan tidak hanya bersumber dari mitos masyarakat saja,namun terlalu banyak faktor kehidupan di dalam sejarah yang tidak memungkinkan perempuan untuk mandiri. Tetapi pandangan feminisme eksistensialis yang diterapkan dalam melihat eksistensi perempuan Sasak dalam novel Sri Rinjani menghasilkan simpulan bahwa Sri Rinjani lebih menyadari keberadaan dirinya sebagai 'Ada' yang bertanggung jawab atas setiap keputusannya. Sri Rinjani melakukan atau bahkan menginginkan sesuatu bukan karena pengaruh dari luar dirinya. Sri Rinjani menyadari bahwa ia perlu menjadi subjek dan menyadari dengan sungguh keadaannya dan cara yang dapat dilakukannya untuk mengatasi keadaannya tersebut.

Dalam perkembangannya perempuan Sasak seperti Sri Rinjani yang merupakan salah satu perempuan yang ingin keluar dari keterpurukan kemiskinan, sehingga ia menjadi pelaku startegi politik 
dengan memperlakukan dirinya sebagai subjek karena selama ini telah terjadi kecacatan eksistensialis terhadap situasi perempuan Sasak di Lombok. Sri Rinjani yang mensyaratkan pernikahannya dengan jaminan masa depan yang baik, yaitu yang mampu mengeluarkan ia dan keluarganya dari kemiskinan.

Hasil penelitian ini menunjukkan bahwa keberadaan perempuan Sasak dalam novel Sri Rinjani yang digambarkan melalui Sri Rinjani tampil sebagai sosok pribadi yang berpikiran terbuka, mandiri dan bertanggung jawab terhadap dirinya. la mampu mengatasi semua masalah dengan berani walaupun harus menerima kenyataan untuk menjadi istri kedua sahabat almarhum ayahnya yang sangat baik. Sebagai perempuan Sasak, Sri Rinjani merefleksikan pribadi perempuan Sasak yang tangguh dan selalu berusaha untuk keluar dari cengkraman ketidakadilan. Dengan demikian, didapat persepsi baru bahwa sosok perempuan Sasak dalam novel ini tidak menduduki posisi subordinat, ia adalah pelaku perbuatan. Dengan kata lain, ia adalah subjek yang melakukan segala sesuatu berdasarkan keputusan keputusannya sendiri.

Perempuan sasak ialah perempuan yang memiliki identitas kelahiran di Lombok. Dimana pada awal mulanya perempuan sasak memiliki khas yang secara turun temurun yaitu bertenun, di masa lampau perempuan sasak masih sangat erat dengan tradisi-tradisi seperti bertenun agar salah satunya selain sebagai bentruk kreatifitas juga menjadi pengakuan bahwa sudah dapat diakui sebagai perempuan Sasak dan dipercayai sebagai seorang seninaq (istri). Sejalan dengan perkembangan zaman beberapa tradisi tersebut bergeser secara perlahan. Tulisan ini menitikberatkan pada bentuk peran pendidikan perempuan Sasak dan apakah dampak positif ketika perempuan Sasak memperjuangkan pendidikan.

Pendidikan merupakan tongkat terbaik untuk menunjukkan diri bahwa ketercacatan eksistensialis perempuan berada jauh lebih baik ketika perempuan di Lombok memiliki ilmu dengan menyetarakan pendidikan, sebagai perempuan Sasak tidak pula melepaskan peran baik sebagai anak atau istri yang 
tentunya dengan ilmu tersebut ialah tuntutan terkuat bahwa perempuan berpendidikan lebih cerdas dalam memposisikan diri.

Pengarang, Dunia Sosial, dan Representasi Perempuan dalam Sri Rinjani (2011) karya Eva Nourma

Pengarang, Eva Nourma, adalah perempuan yang tergolong dalam kelompok sosial perempuan terdidik dan moderat. Gagasan dan pemikirannya juga terlihat dalam novelnya yang lain, Perempuan Tulang Rusuk Dua (2009), satu novel yang ditulis bersama Salman Faris. Dalam menghadapi lingkungan sosialnya, Eva Nourma bersifat akomodatif sekaligus memberikan "perlawanan" atau suara perubahan dalam sebuah tradisi, terutama kedudukan perempuan dalam masyarakat Sasak.

Melalui novelnya ini, Eva Nourma pada dasarnya memberikan sebuah tanggapan atas nasib perempuan Sasak. Intinya, perempuan Sasak diajak untuk mengubah nasibnya melalui pendidikan. Baginya, pendidikan menjadi jalan untuk perubahan sosial atau transformasi sosial. Perempuan harus mengambil bagian dalam transformasi tersebut melalui pendidikan. Hal ini yang dihadirkan atau disuarakan melalui novel Sri Rinjani tersebut. Sebab, melalui pendidikan tersebut, perempuan dapat mengubah nasib, kedudukan, dan cara pandang hidupnya. Dengan demikian, perubahan sosial dalam masyarakat Sasak terwujud.

Namun, dalam suara kelompok moderat ini, Eva Nourma tampaknya tidak memberikan gagasan mengenai agama Islam dan kebiasaan masyarakat Sasak, terutama perempuan Sasak. Masyarakat Sasak, terutama kelompok perempuan, tidak terlepas dari konstruksi keagamaan dan tradisi setempat. Gagasan mengenai agama dan kebiasaan ini tampaknya dikomentari dengan sangat hati-hati. Namun, secara umum, gagasan ini dilihat secara moderat ataupun mengikuti perkembang zaman. Reaktualisasi nilai-nilai tardisi dan keagamaan perlu dilakukan untuk menghadapi konteks perubahan sosial pada masanya.

Gambaran perempuan yang miskin, bodoh, dan terbelakang yang dihadirkan dalam teks novel Sri 
Rijani ini merupakan sebuah bentuk sindiran sekaligus ajakan untuk mengubahnya. Gagasan keagamaan yang diungkapkan dalam teks tersebut adalah gagasan yang moderat sekaligus tetap pada nilainilai keislaman. Perempuan haruslah terdidik, maju, dan moderat dalam menghadapi perubahan sosial. Namun, perempuan harus tetap memegang konsep utama dalam agama Islam, yakni tetap menjadi makmum bagi laki-laki dalam hubungan keagamaan.

Gagasan yang moderat tentang peran perempuan Sasak yang diekspresikan dalam teks Sri Rijani oleh Eva Nourma ini merupakan sebuah tindakan sosial yang dilakukan oleh kelompok moderat terdidik yang diwakili oleh Eva Nourma. Perempuan, bagi kelompok ini, harus ikut ambil bagian dalam transformasi sosial. Sebelum mengambil bagian, perempuan harus dibekali dengan kekuatan untuk bisa masuk ke dalam arena itu. Kekuatan itu adalah pendidikan. Melalui pendidikan, perempuan dapat mengubah nasib dirinya dan berperan dalam mengubah lingkungan sosial atau struktur sosial yang "memenjarakan" potensi dan keberadaannya.

\section{SIMPULAN}

Teks novel ini merepresentasikan gagasan tentang keterbelakangan perempuan Sasak. Namun, representasi ini pada hakikatnya merupakan sebuah ajakan untuk perubahan. Melalui teks ini, Eva Nourma beserta kelompoknya mengajak perempuan Sasak untuk mengubah nasibnya. Setelah nasib dan kedudukannya berubah, perempuan Sasak dapat berpartisipasi dalam perubahan sosial di lingkungannya atau mengubah struktur sosial yang ada.

Dalam menghadapi gagasan itu, perempuan Sasak, menurut Eva Nourma, harus tetap pada prinsipnya, yakni tetap menjalankan tradisi dan praktik-praktik keagamaan, yakni Islam. Dia tetap menjadi makmun bagi laki-laki. Namun, nilai-nilai keagamaan itu dikontekstualisasikan ke dalam persoalan kekinian, terutama masalah pemberdayaan perempuan. Perempuan Sasak berada dalam perubahan zaman. Salah satu alat atau cara yang paling 
efektif dalam menghadapi hal itu adalah melalui pendidikan.

\section{DAFTAR PUSTAKA}

Beauvior de, S. (2016). Second Sex Kehidupan Perempuan. (Cet. 1). Yogyakarta: Narasi-Pustaka Promethea

Goldmann, L. (1977). Toward A Sociology of the Novel. London: Routledge \& Kegan Paul.

Lathief, S.I. (2008). Sastra: Eksistensialisme Mistisisme Religius. Lamongan: Pustaka Ilalang.

Nurgiyantoro, B. (2000). Teori Pengkajian Fiksi. Yogyakarta: Gadjah Mada University Press.

Nourma, E. (2011). Sri Rinjani. Pancor Selong Lombok Timur: STKIP Hamzanwadi Press
Ratna, N.K. (2007). Teori, Metode, dan Teknik Penelitian Sastra. Yogyakarta: Pustaka Pelajar.

Rosemarie, T. (2006). Feminist Thought: A Comprehensive Introduction. USA : Westview Press

Susanto, D. (2016). Pengantar Kajian Sastra. Yogyakarta : CAPS

Thornham, S. (2010). Teori Feminisme dan Cultural Studies. (penerjemah: Asma Bey Mahyuddin). Yogyakarta: Jalasutra.

Wibowo, A. (2008). "Simon De Beauvior: Feminisme Eksistensialis".

http://staff.blog.ui.ac.id/arif51/ 2008/07/28/simon-debeauvoir-feminismeeksistensialis/. diunduh pada tanggal 12 Mei 2011. 